\title{
FORUM
}

\section{MANEUVERING AS AN INTEGRATION STRATEGY AMONG IMMIGRANTS}

TÜNDE TURAI ${ }^{1}$

\begin{abstract}
Analysis of the integration strategies followed by migrants provides good insight into the process of integration and helps with understanding the interaction between migrants and the receiving society. This approach integrates the micro, the meso and the macro levels of social scientific analysis because migrants face social challenges at different levels and their survival strategies are reactions to this whole intertwined complex. I propose to approach the integration of the migrants by investigating their techniques of maneuvering. Most migrants try to maximize their contact with the receiving community. Even those who live in rather segregated ethnic enclaves maintain some basic contacts with the surrounding world.

In this paper I present the results of an analysis of narrative and semi-structured interviews conducted with immigrants who are living in Hungary and focus on the 'slalom' nature of the technique they follow in trying to avoid the integrationrelated traps in bureaucratic processes, the labour market and social life in general.
\end{abstract}

KEYwORDs: third country immigrants, integration, inventive strategies, maneuvering (slalom) technique, selective discrimination, Hungary.

\section{INTRODUCTION}

In Hungary, immigration has been linked with nation-building policies and mainly concerns ethnic Hungarians from neighboring countries due to Hungary's geopolitical position in the region. The interest of scholars has reflected this same tendency and interpretations of migration have been interconnected with the issue of ethnicity for a long time (Tóth 2011). Third country immigrants have received much less attention; research projects that

1 Tünde Turai is a research associate at the Institute of Ethnology of the Hungarian Academy of Sciences, e.mail: turai@etnologia.mta.hu 
have as their focus non-ethnic Hungarian migrants are still very few in number. In this analysis I turn my view towards these third country immigrants (among whom Hungarian ethnic co-members are in the minority). I approach the integration of the migrants by investigating their maneuvering (or slaloming) techniques to reveal complex adaptation process. There is no clear protocol for integration; the administrative-political procedure is vague. Migrants need to invent informal and flexible strategies to reach their goals and they need to be creative in order to overcome these shortcomings and to make progress with the process of integration. The maneuvering techniques they employ are the informal policies they have elaborated to make rigid and deficient systems and conditions work for them. Most migrants make huge efforts to make contact with the receiving community, to escape from the margins and to be integrated into their new milieus. Even those who live in ethnic enclaves need and/or prefer to have some basic contact with the surrounding world. But, in many cases, this means working hard and paying huge social and emotional costs, so there are many who never succeed. They develop flexible slaloming techniques as a way of surviving in their new communities and their efficiency and success depends on many personal, cultural, social and structural variables.

The approach taken in this paper opens up new vistas into Hungarian migration policy and helps with reflection into the attitudes of Hungarian society towards different groups of others; moreover it can reveal the hidden mechanisms that third country immigrants employ in order to overcome the obstacles to the integration process.

\section{THEORETICAL FRAMEWORK}

Integration represents a complex interaction between a host society and its immigrants and the responsibility and the active participation of both sides is important in reducing (or at least minimizing) tensions and leading to successful (or at least acceptable) incorporation. According to the given hierarchy between the receiving society and the 'unwanted' 'unwaited' uninvited new arrivals, the risk exists that immigrants will be considered more responsible for their integration process and more will be expected of them than of the hosts. This unequal distribution of power reflects the unsolved and unclear place of the immigrants in the receiving country, or more precisely, a lack of understanding about how they fit into the concept of $u$, and what they are allowed in terms of their use of our terrain. The tension stems from the strong relationship between the idea of nation and citizenship, as many scholars have already demonstrated. Brubaker argues 
that the nation-state is not just an institutional and socio-psychological reality (namely, a distinctive way of organizing and experiencing political and social membership), but that it is also an idea and an ideal that shapes political and social membership. Therefore the disposition to include immigrants as equal members may be limited (Brubaker 2006). In contrast, Soysal states that in the postwar period the relationship between the other, alien and the host polity changed. More intense discourse about personhood and human rights broke the bounded universality of national citizenship, generating contiguities beyond the limits of national citizenry (Soysal 1994). Even if there appears to be a clear contradiction between these approaches, Christian Joppke combines these models in his interpretation, concluding that "in both nationally exclusive and postnationally inclusive perspectives immigrants are not expected to assimilate": for advocates of national closure, assimilation was impossible and undesirable and threatened to destroy the ethno-cultural texture of the nation; for postnationalists, assimilation was undesirable and unnecessary because it violated the dignity of the individual (Joppke 2008).

Immigrants present a significant challenge to a host society and their presence inevitably leads to reflective questions being raised. The nation as a legitimizing principle of the state needs to be reconsidered, along with the nature of models of integration (which typically run from assimilation to multiculturalism); moreover the meaning of 'successful integration' has to be re-conceptualized; the community and the anomalies of membership must be reinterpreted and the role and responsibility of different actors (states, subnational groups, the civil sphere and individuals) in the process of integration need to be seriously reconsidered (Alba \& Nee 1999; Brubaker 2006; Favell 2001; Gans 1999; Joppke 2008; Portes 1995; Rumbaut 1999; Soysal 1994; Süssmuth \& Weidenfeld 2005; Zhou 1999).

Migration presents a significant challenge to immigrants too. The difficulties experienced genuinely test the abilities of the immigrants and their resources. Taking up residence in a new country influences the individual in many ways and also leads to changes in their families. According to their new circumstances the immigrants have to rethink their relationships to the sending country and to the personal networks they have left behind; they have to reflect on their capacities and the different types of capital they have and on their aspirations and intentions; they need to reevaluate and change their life styles and their life strategies and they have to reorganize their lives and mentalities according to new opportunities and constraints (Foner 1999; Pessar 1999; Melegh \& Kovács 2008; Cohen 2011).

In brief, integration depends on the one hand on cultural, social and economic factors and the individual abilities of the immigrant, but on the 
other hand also on how host society views immigrants and on what resources it offers them. In addition, the state-mandated regime for incorporation is very important. The essence of the interplay is that with their accumulated capitals immigrants adapt to the structures and attitudes presented by the host country, which in turn responds, and the two sides mutually and perpetually influence each other.

The following interpretation takes the classification structure of Attila Melegh and Irén Gödri as its analytical framework. According to these authors, the complex system of integration is composed of four elements: structural integration (integration into the labour market and the economy, integration into the education system, accommodation, integration to the welfare system, political integration), cultural integration (linguistic and communicational integration, cultural adaptation, religious customs), social integration (integration into family, friendships, groups, organizations) and identification integration (adaptation to the local community, estimation of the self according to the new conditions, level of contentment, feeling at home, experiencing discrimination, wishing to return or to go further, intention to demand citizenship, migrant identity) (Melegh \& Gödri 2009).

\section{METHOD AND DATA}

The analysis which is presented is based on recently-collected (2009) narrative and in-depth interviews conducted with 22 long-term, third country immigrants living in Hungary (residents who had been in Hungary for only a short period or who had a fixed duration of stay were excluded) ${ }^{2}$. The methodology chosen seemed to be the most appropriate for two reasons. Firstly, the interviews and the very personal nature of the non-formalized, non-structured, not question-response-type interviews were based on mutual trust and openness to self-expression, and we expected that the discussions might cover sensitive issues like illegal strategies, experiences from the margins and discrimination in the family. Secondly, inviting people to tell stories about their migration experiences and integration techniques was a way to make sense of the personal significance of integration and its role in the interviewees' personal careers.

2 The majority of the interviews (16 of them) were collected in the frame of a project undertaken at the Corvinus University of Budapest (Civic Discussions about Immigration, http://www.unicorvinus.hu/fileadmin/user_upload/hu/tanszekek/tarsadalomtudomanyi/szti/etk/migracios_ kotet_angol.pdf). The remaining 6 interviews were done by the author. 
The sample was identified and expanded using the snowball technique with several entry points to avoid long chains. The researchers strongly desired the formation of a varied group which would bring together interviews from individuals from different countries, age groups and social background. Three interviewees had arrived during the socialist era so they had confronted the social and economic conditions of the previous political regime; twelve of them arrived between 1990 and 1999 and seven after 2000. The majority were highly educated; 16 had university diplomas, 4 had bachelor degrees (one of them was about to graduate from university) and only 2 of the interviewed had only attended primary school. The dominance of highlyeducated individuals could have easily shape the preconception that the more educated an immigrant, the more successful they are at integrating; however, the sample group reported many instances of discrimination and unsuccessful integration. Regarding the sending country, 9 were from Europe (6 Ukrainian, 3 ex-Yugoslavian ${ }^{3}$ ), 5 were from Asia (3 Chinese, 1 Mongolian, 1 Iraqi), 6 were from America (2 from the US, 1 from Ecuador, 1 from Costa Rica, 1 from Mexico, 1 from Cuba) and 2 were from Africa ( 1 from Tanzania, 1 from Cameroon). There were 12 men and 10 women. Five were aged between 2029 , four between $30-39$, seven between $40-49$, and six between $50-59$. Five were single, 16 married (9 had at least one child) and 1 was divorced at the time of the interview.

The main topics of the interviews included personal migration stories, encounters with different segments of the receiving society, encounters with Hungarian culture, relationships with the sending country and co-ethnic members living in Hungary, family background, future plans, integration plans, steps taken in the integration process and experiences of these steps, instances of discrimination, and identity.

The analysis focuses on the immigrants. Although this can be considered a micro-analysis, it's interpretation provides a larger picture about the broader processes of migration. Analysis of the integration strategies is promising from two points of view: on the one hand it can serve to integrate the micro, the meso and the macro level of social scientific analysis because migrants directly face social challenges at different levels and their survival strategies are reactions to this whole intertwined complex; on the other hand, analysis

3 I prefer here to use the term ex-Yugoslavia instead of identifying the specific country of origin for several reasons: when these individuals left their homes, the states as they are identified today often did not exist; all of the interviewees had run away because of the war; their previous place of residence was not safe and due to the war they had moved many times. 'Localising' them according to the modern geopolitical structure makes no sense and could lead to misunderstanding. 
of the integration process can be used to reflect on the interaction between the migrants and the receiving community in a detailed way and to provide information about the behavior of both immigrants and hosts.

\section{MISMATCHES AND TENSIONS}

Hungarian immigration policy is ideologically mixed. Access to membership of the community is ethno-genealogically determined (a selective exclusion model), but at the same time it is also defined using a civic-territorial principle. International human rights and the general principles of the European Union which refers to the free movement of its citizens also play a role.

In the post-socialist area the first Hungarian act to control citizenship and migration was codified in 1993 through Act LV. According to this piece of legislation, Hungarian citizenship is based on the ius sanguinis principle. The ius soli principle is applied to a very small group: children of stateless parents born on Hungarian territory and orphans without known origins can receive Hungarian citizenship. In all other cases Hungarian citizenship can be acquired through an individual process of application. The administrative process requires that the immigrants meet some social, financial and residence-based criteria and have a clean criminal record. Act XLVI of 2005 further defined a privileged group and thereby expressed the clear intention of the state in the naturalization process: immigrants with Hungarian origins were awarded the chance to go through a simplified naturalization procedure. Thus the ethnic principle of citizenship became more significant ${ }^{4}$ (Tóth 2011, Sárosi 2011). Accession to the European Union created one more privileged group (citizens of EU member states), but their privileges remained at the level of settling down as residents; the more permissive gates for ethnicallyconceived Hungarian citizenship were not open to them. Third county immigrants (with the exception of a small group of Hungarians from Ukraine and Serbia) face a complicated administrative process consisting of several steps (visa, residence visa, national visa, residence permit, and settlement permit, citizenship) in order to legalize their status.

The administrative process prescribed by migration policy is not easy to follow (see also Kováts 2011). The main tensions stem from two mismatches. First, the integration regime is built on loosely interlocking parts, the relevance of principles is rather particular than general and the system thus

4 The third important modification to the law issued in 2010 is not discussed in this paper as it is not relevant to the sample interviewed in 2009. 
contains gaps and pitfalls and often-complicated expectations are not clear or well-communicated. Second, there is no consensus about immigration in Hungarian society. The population is divided to a significant extent about the topic, and a rupture also exists between the principles enshrined in legislation and the popular conception of who should be favored to access the Hungarian "national body". This mismatch leads to more problems than those caused by the integration regime itself (by this, I mean that the conflicts between legislatory practice and social practice can lead to discrimination). Moreover, for different areas of integration, different principles may dominate: the relationship between eligibility based on ethno-genealogical identity, civicterritorial origins and international human rights and membership of the European Union is not well elaborated. Thus there are no models, welldefined paths or procedures for immigrants to follow. They are constrained to maneuvering in an inventive manner on this difficult terrain.

\section{STRATEGIES FOR GETTING INTEGRATED}

The process of being transformed from an exotic plant to a houseplant, as a Chinese interviewee very expressively described the integration process, happens in different areas: structural, cultural, social and identification. Moreover, integration into the host society is not a linear process. The multidimensional characteristic of the phenomena was highlighted by John Berry in his model of acculturation. He approached the phenomenon from a cultural and psychological point of view and distinguished 4 acculturation strategies: assimilation, separation, integration and marginalization. ${ }^{5}$ The Berry model was an important advance over early linear models and influenced later research. However, the empirical research that tried to verify the model met with mixed results so Erik Cohen declared that there was a need to improve it. Cohen developed a multi-directional model and theorized that immigrants were at the center of three reference groups (home culture, host culture and the culture of the co-migrant community), all of which could have a positive

5 The 4 strategies are the following: assimilation is when individuals do not wish to maintain their cultural identity and seek daily interaction with other cultures, separation is when individuals place a value on holding on to their original culture and wish to avoid interaction with other cultures, integration is when there is an interest in both maintaining one's original culture and interacting with other cultures, marginalization is when there is little possibility in cultural maintenance and little interest in having relations with other cultures. (Berry 1997) 
or negative impact on attitudes to immigration ${ }^{6}$ (Cohen 2011). It seems that understanding the immigrants' presence in the receiving country needs a very sophisticated analysis that takes into consideration different levels and forms of interaction.

It is also important to mention that the intentions of the immigrants concerning the depth and the nature of accommodation to the new milieu may vary. Research from the same year as the research for this paper was conducted (2009) reflects that the plans of immigrants may differ according to their ethnic origins, economic, social and cultural background, personal aspirations and networks and experiences with the host society. It seems that Hungary is mostly a transit country; becoming permanently established and completed naturalized here is the intention of less then half of all immigrants (Örkény 2011). However, once they have arrived in Hungary immigrants can not avoid interacting with the host society, meeting the demands of different authorities and becoming immersed into the receiving country to a certain degree.

My approach focuses on the modes that immigrants employ as they interact (to a different extent) with the host society as they cope with their uncertain and unstable statuses. The following description of strategies illuminates the background of this very complex process. Integration into different segments of the host society is realized through the dynamic and inventive application of formal and informal strategies on each level (Melegh 2009).

During the process of migration, the immigrants move backwards and forwards in terms of integration and there are periods of partial integration and 'disintegration'. I argue that it is not always the immigrants' decision whether to get integrated into the host community. I believe that it always has to be taken into account that immigrants can manage the immigration process only with difficulty so they are liable to fall off the legal path of immigration from time to time, until they succeed in finding a solution for getting back on the legal path. I should add that this is not a strictly migration-specific phenomenon; natives also struggle with many such problems. But immigrants are in a more disadvantageous situation; they are less well protected and they face many more obstacles. As a result, the likelihood and the intensity of the need to maneuver among different obstacles and to find solutions to different immigration-related challenges is much higher.

6 Cohen distinguishes 8 types of acculturation: group integration, group nostalgic insulation, individual integration, individual nostalgic insulation, group acculturation, group insulation, assimilation and marginalization/individualization. Cohen 2011. 


\section{Maneuvering among offices and officials}

Structural and institutional integration is codified in clear and strict legislation; however, this is not easy to follow (Kováts 2011). Bureaucracy is more rigid, slower and more complicated than is strictly required; moreover it is also expensive, often inconsequential and fragmented into hardly perceptible parts. The legislative order appears to be insufficient for solving the tasks created by the reality of immigration.

At the international level gaps may occur in the legislation of different countries. Latin American interviewees complained about the obstacles they met in the process of getting married to Hungarian citizens in Hungary, an observation which demonstrates that Hungarian bureaucratic processes are not equivalent with the bureaucratic formalities of other countries (in addition, interviewees complained that Hungarian administrators refuse to be flexible and open). For example, a certificate stating that the interviewee was not married (issued by an immigrant's country of origin) was refused by Hungarian officials. Hungarian legislation permits marriage only in the case that an applicant has a document proving that the document-holder is allowed to marry a Hungarian citizen. The interviewee's attempt to explain the similarity between the content of their own documents and the official declaration required by Hungarian immigration officials was in vain. As a result, the interviewees had to ask for help from their embassies: the lucky Ecuadorian woman and Mexican man managed to solve their problem in Budapest but a not-so-lucky Costa Rican man and Cuban woman found that the nearest appropriate embassy they could complete the necessary documentation was in Germany. The situation was complicated by the fact that the applicants' tourist visas were close to expiring and the time they had allowed for the task and the time actually needed to complete this bureaucratic task were not in harmony.

Official monopolies may create problems as well. In Hungary there is a monopoly on translating and notarizing immigrants' documents. There are complaints not just about the shockingly high prices of this but also because of the monopoly situation and the inadequate service provided. Our Latin American interviewees reported that the office concerned has no translators for the type of Spanish dialog officially used in their home countries. So, according to a strict interpretation of the regulations, their papers could not be translated. Luckily, the official let them translate the text, then signed the document - for the usual price, of course.

The discriminatory attitudes of some officials may be counterbalanced by the more positive attitudes of others. The immigrants reported that succeeding 
at the Immigration and Naturalization Office often depends on the officials themselves. This means that the regulations are interpreted, observed and/ or communicated to the immigrants in different ways. As the system doesn't permit the applicant to choose the official who deals with the paperwork, their chances depends on their luck. One Tanzanian interviewee mentioned having the help of a senior official. This individual had had difficulties at a preuniversity school which specializes in facilitating immigration. He had been discriminated against by his former schoolmaster who wanted him to fail his final exam which would have blocked him from getting into university and meant that the immigrant would have had to remain in Hungary. Following the advice of a fellow-countryman, he went to the Ministry of Education and asked for the help of a specific civil servant.

Immigrants can be trapped due to the inconsistencies in the immigration system. One example of how this can happen is the process of registration. A social security number can be obtained through having a residence card, but gaining the status of resident can only be done through having a social security card. The problem is mainly solved by the private sector: temporary social insurance can be purchased for a much higher price than usual (and is valid for a much lower level of services). Our Costa Rican interviewee solved this problem in a creative way: she applied for both social security number and residence card on the same day.

\section{Using the help of 'specialists'}

The disadvantages that immigrants face (typically communication problems and a lack of information) and the problems that stem from the rigidity and complicacy of the administrative system have led to the emergence of a special group: students, administrators and lawyers are now ready to facilitate the structural integration of immigrants. Their services vary from offering very minor forms of help (such as standing in queues or completing application forms) to managing the whole complex system of administration. These service providers typically advertise in newspapers (whose target audience is certain ethnic and migrant groups) but the information is also diffused through informal channels from immigrant to immigrant. Their clients are mostly Chinese citizens (this ethnic group appears to favor the use of this strategy) but other immigrants also mention the help of lawyers. Here we should point out the creativity of the host society, too, who have realized the difficulties which exist at the interface between the desires of immigrants and the bureaucracy they face, and use this as a good source of profit. 


\section{Maneuvering on the margins: temporary illegality, partial illegality}

The labour market is one of the most difficult terrains in the integration process for immigrants despite the fact that they are overqualified in comparison to the host society (Perttu 2009). The labor market is an important mechanism for inclusion/exclusion (Sassen 1995). Such inclusion or exclusion may result in different outcomes: segmented labor markets, ethnic enclaves or the informal economy (Portes 1995; Massey 1999). The disadvantages to immigrants are the complicacy, slow speed and expense of bureaucracy, discrimination from the host society, the structure of the labour market and any 'deficiencies' the immigrants may personally have.

Changes in regulations are one factor which pushes immigrants into undertaking illegal activity or having an illegal status. If the immigrant is poorly informed, does not have enough time, is not prepared or lacks social capital, they may find themselves outside the law. A doctor from China reported that Hungarian authorities withdrew authorization of Chinese health centers in 1998 , so he continued working without permission. Patients continued to come to consultations and the doctor treated them, but he took his name-plate off the door. Five years later he became authorized to practice medicine again, so he put his name-plate back and continued with his work, just as before.

As bureaucracy acts more slowly than the demands of life itself may require, immigrants need to work illegally for shorter periods. Life doesn't stop for bureaucratic processes. A man from the former Yugoslavia reported that whenever he was in such a situation he easily found part-time jobs. He worked in restaurants, in construction, he took in private students; he undertook any job he could in order to survive:

...so, Monday I just went onto the streets. It was easy for me, because I already knew the city, I knew it really well. And I went from place to place (...) everywhere where I thought that there would be a possibility (...) I didn't select. If someone needs money, or something, he/she can not select what work they do, that's what I think.

Changes in the statuses of immigrants may also create legal gaps. The problem mainly occurs when students finish studying and decide to work. The privileged status they enjoyed for the period of their study then expires and they have to apply for another type of visa that is much more difficult to get. Interviewees from Iraq and Tanzania reported many difficulties in this respect. They had temporary visas for this uncertain period but even if these 
visas did not allow them to work they still had to earn some money for their families and themselves.

The limited nature of the different legal statuses may also lead to other constraints. The Hungarian student visa allows students to work for a very restricted amount of time. Wives who come to Hungary for the purposes of family reunification can't work until they get a residence permit; all their struggles and maneuvering techniques may fail and they may remain unable to improve their situations for a long time. One of our Ukrainian interviewees complained that she could only earn money doing domestic work. Another Ukrainian woman can't obtain a disability pension because she is stateless and hasn't yet received Hungarian citizenship. Naturally, the failure to get integrated into a primary sector of the labor market pushes immigrants to earn their living in the black or secondary sector.

Until the accession to the European Union, immigrants living in Hungary employed a very popular strategy: the easy reconciliation of tourist status with illegal work. Between 1990 and 2004, Europeans, some Asians (mostly citizens of the post-socialist countries) and citizens of the US could stay in the country as tourists for 30 days without any special papers or a visa. If they wished to begin a new 30 day period they just crossed the Hungarian border, spent some hours in a neighboring country, then came back and continued their everyday lives. Of course, the money, the time and the effort expended doing this was rationally appraised as being worthwhile; a partially legal strategy for staying in Hungary won out over struggling with the authorities.

Having a social network is very helpful at all stages of integration. It makes incorporation into the labour market easier, but it also helps when managing administrative problems. Friends, previous teachers, classmates and colleagues all play an important role in bridging the gaps created by discriminative processes, the lack of solidarity and indifferent attitudes towards immigrants and the extra burden these create. Thus those who are rich in social capital can manage their lives much more successfully than others. The Chinese doctor mentioned earlier was even able to accelerate bureaucratic processes and make them more effective:

...my wife came after me in 2001. I was lucky in this, too. Around 2001, it was very difficult to get a visa to Hungary, especially for a longer period. (...) Then again somebody helped me. A friend of one of my patients. (...) The acquaintance of my patient was working at some kind of authority, I don't know where. I think you understand. I am a doctor. Doctors are in a privileged situation. 
As a final remark concerning structural integration it is important to mention that not all the immigrants succeeded in escaping from the margins. The above-mentioned woman who was constrained to work in the domestic sector illustrates this fact. In many cases the immigrants' strategies are unsuccessful and they are doomed to remain outside the institutional framework for longer or shorter periods. Interviewees faced discriminative attitudes when they applied for welfare services (such as family allowance, health care, maternity benefit or disability pensions) and when they went to medical centers, even if they had the right to these services. Moreover, living in the margins is a very dangerous trap as it can easily reinforce disadvantages: those who lack social capital are more likely to enter the secondary labor market; here they earn less so they have to work more to survive, thus they have less opportunity to find better jobs and to legalize their status, and last but not least they may also loose the opportunity of learning the Hungarian language which will keep them permanently on the margins.

\section{ETHNIC ENCLAVES}

Ethnic enclaves represent special 'solutions' for some immigrants to manage their migration processes. Those who are unsuccessful in the integration process or who prefer to remain outside of the Hungarian community can have a more or less complete/integral life among their fellow countrymen. Ethnic enclaves are multileveled and institutionally complete (Portes 1995); they offer dense and familiar social networks, opportunities for work, accommodation, the fulfillment of cultural needs and social protection. In contrast to Hungarian public opinion, it is not only the Chinese that live in ethnic enclaves in Hungary. Research shows that any type of ethnic group may form an enclave: our Mongol interviewee reported how her parents are segregated in a Mongolian community (and detailed the huge effort she made to escape this closed world); the same problem was reported by a second generation Chinese girl; wives who came from Ukraine could only find work and friends among fellow Ukrainians and Russians; a Ukrainian citizen with Hungarian ethnicity spent years in Hungary without making contact with the host society (she lived and worked together with kin); there also exists an ethnic enclave of Serbian citizens with Hungarian ethnic background. A Cameroonian man reported that there even exists a special international group 'above' the host society that is populated by highly-educated, Englishspeaking, short-term resident, globally mobile immigrants. 


\section{Maneuvering with the help of the host society}

As I have already detailed, the social network formed by Hungarians may help immigrants a lot with structural integration. Below I present details about this informal level of integration. Many of the immigrants complained that Hungarians are closed, arrogant, morose and reserved. They confess that Hungarians are like this also among themselves as well, and this is a real challenge for them. An ex-Yugoslavian immigrant mentioned that during the eight years he lived in Hungary he was never invited to the home of a Hungarian.

The most accessible channels into informal Hungarian society are formal frameworks: schools and workplaces. Immigrants make contact mostly in these contexts. Spontaneous interactions were very rarely mentioned during the interviews, it seems to be almost impossible for immigrants to make friends spontaneously. It is most probable that colleagues and classmates and friends of classmates will become part of the social networks of immigrants.

The other very important channel for informal integration is the immigrants' neighborhood. Physical proximity gives the occasion for the immigrant to meet Hungarians. Such encounters are only a possibility and do not necessarily lead to 'good' contacts; experiences described by the interviewees are very mixed. They mentioned both formal greetings and reserved communication but also reciprocal help and more intensive visits. In some cases, in the first period of the immigration process, immigrants needed to share their apartments with others: an ex-Yugoslavian couple rented an apartment together with a Hungarian couple and a Chinese family rented a room from an old Hungarian lady. Co-residence proved to be a real base for good friendship.

A very special integration strategy was reported by a Chinese woman. Her parents decided that it would not be enough for her to be socialized through school; a deeper process of cultural integration would be needed. They firstly paid a private teacher to teach her the Hungarian language and culture and then later paid a Hungarian family to share their life with her for three months.

My parents thought that it would not be enough to learn, and I also agree with them; moreover my teachers also told me that it is not enough to learn how to say words like 'lemonade', 'the lemon': I should also learn that... I don't know... what the 'Mézga family' or 'Captain Tenkes' is [Hungarian cartoon and film series from the 1960s]... So, these cultural things are 
important... When we eat, and things like that, we don't put our hands under the table during eating, cultural things are important. Concretely, how does a Hungarian family live? ... They get up in the morning, what do they eat?... I would never eat bread with butter myself, because I hate butter, but they eat bread with butter. So, at least I know this.

\section{Collaboration with other immigrants}

Being in a similar situation may link immigrants with widely varying backgrounds. However, very few relationships with others were mentioned. Interviewees mostly referred to the Romanian citizens of Hungarian origin as being the most collaborative and supportive immigrant group. This image can be interpreted as being a visualized ideal of an immigrant diaspora; moreover it represents a kind of complaint about the members of their own nationality. In this critique the main element is complaint - about suffering caused through the lack of help with the integration process.

\section{The role of family in integration}

The role of family members seems to be very ambivalent. The spouse is considered to be an important connection with the host society, but some female immigrants reported being confined to doing housework and being isolated from society. A similar statement concerning in-laws was reported: the immigrant may experience very positive integrative attitudes on their part, but it is also possible that they experience very painful discrimination as well. The role of children is also ambivalent. Undoubtedly, having children more deeply involves parents into the host society through the need for cooperation with a greater variety of institutes needed for socialization of the child. It is also clear that having children was connected with deeper feelings of being at home in the new country. But children can also serve to isolate parents from the host society (especially those who live in ethnic enclaves) because children often become mediators between the host society and their parents, removing from the adults this need/opportunity. 


\section{CONCLUSION}

The research shows that Hungarian migration policy and the host society itself create many difficulties for third country immigrants in their integration process. First, the integration system is rigorous and is fragmented into poorlycoordinated components. Moreover, it favors immigrants with Hungarian origins. Second, immigrants often face discrimination from the Hungarian community. As a result, immigrants are forced to apply a variety of strategies in order to evaluate and further their process of integration which requires being very creative and inventive in maneuvering among the obstacles. This difficult slaloming technique challenges them more than would be the case if immigration policy were more transparent and accessible (Tóth 2011). Making efforts to bridge legislative gaps, to avoid traps, to overcome obstacles and to survive difficult periods costs them dearly in all senses: emotionally, socially and materially. Their main sources of help are members of their coethnic group and their own creativity at problem-solving. Members of the host society and members of other immigrant groups may also offer some help, but this contribution is limited.

\section{REFERENCES}

Alba, Richard \& Nee, Victor (1999), "Rethinking Assimilation Theory for a New Era of Immigration", in: Hirschman, Charles - Kasinitz, Philip - DeWind, Josh, eds., The Handbook of International Migration: The American Experience, New York, Russell Sage Foundation, pp. 137-160.

Berry, John W. (1997), "Immigration, Acculturation and Adaptation", Applied Psychology Vol. 46, No. 1, pp. 5-68.

Brubaker, Rogers (2006), "Immigration, Citizenship and the Nation-State in France and Germany: A Comparative Historical Analysis", in: Messina, Anthony M. - Lahav, Gallya, eds., The Migration Reader. Exploring Politics and Policies, Boulder, London, Lynne Rienner Publishers, pp. 406-437.

Cohen, Erik (2011), "Impact of the Group of Co-migrants on Strategies of Acculturation: Towards an Expansion of the Berry Model", International Migration Vol. 49, No. 4, pp. 1-22.

Favell, Adrian (2001), Philosophies of Integration. Immigration and the Idea of Citizenship in France and Britain, $2^{\text {nd }}$ ed., Houndmills, Palgrave \& Centre for Research in Ethnic Relations, University of Warwick.

Foner, Nancy (1999), "The Immigrant Family: Cultural Legacies and Cultural Changes", in: Hirschman, Charles - Kasinitz, Philip - DeWind, Josh, eds., The Handbook of International Migration: The American Experience, New York, Russell Sage Foundation, pp. 257-264. 
Gans, Herbert J. (1999), “Toward a Reconciliation of "Assimilation” and "Pluralism": The Interplay of Acculturation and Ethnic Retention", in: Hirschman, Charles Kasinitz, Philip - DeWind, Josh, eds., The Handbook of International Migration: The American Experience, New York, Russell Sage Foundation, pp. 161-171.

Joppke, Christian (2008), Immigration and the Nation-State. The United States, Germany, and Great Britain, Oxford, University Press.

Kováts, András (2011), “A honosítási intézményrendszer - Kvalitatív kutatási tapasztalatok" [Institutions for Naturalization - Qualitative Research Experiences], in: Kováts, András, ed., Magyarrá válni. Bevándorlók honositási és integrációs stratégiái [Becoming Hungarian. Migrants' Strategies for Naturalization and Integration], Budapest, Institute for Minority Studies, pp. 251-266.

Massey, Douglas S. (1999), "Why Does Immigration Occur? A Theoretical Synthesis", in: Hirschman, Charles - Kasinitz, Philip - DeWind, Josh, eds., The Handbook of International Migration: The American Experience, New York, Russell Sage Foundation, pp. 34-52.

Melegh, Attila (2009), A bevándorlói interjúk elemzése [Analysis of Interviews with Immigrants], Manuscript.

Melegh, Attila - Gödri, Irén (2009), Integrációs modell ('Integration model'). Manuscript.

Melegh, Attila - Kovács, Éva (2008), “In a Gendered Space. Forms and Reasons of Migration and the Integration of Female Migrants", Demográfia (Special English edition) Vol. 50, No. 5, pp. 26-59.

Örkény, Antal (2011), “A harmadik országbeli állampolgárok honosítással kapcsolatos vélekedései, és ezek összefüggése a migráció különféle aspektusaival” [Attitudes of Third-Country Nationals Toward Naturalization and Their Relationship to Various Aspects of Migration], in: Kováts, András, ed., Magyarrá válni. Bevándorlók honositási és integrációs stratégiái [Becoming Hungarian. Migrants' Strategies for Naturalization and Integration], Budapest, Institute for Minority Studies, pp. 127-180.

Perttu, Salmenhaara (2009), "Social Capital in the Mobilisation of Human Capital", Demográfia Vol. 22, No. 5 English Edition, pp. 97-123.

Pessar, Patricia R. (1999), "The Role of Gender, Households, and Social Networks in the Migration Process: A Review and Appraisal", in: Hirschman, Charles Kasinitz, Philip - DeWind, Josh, eds., The Handbook of International Migration: The American Experience, New York, Russell Sage Foundation, pp. 53-70.

Portes, Alejandro (1995), "Economic Sociology and the Sociology of Immigration: A Conceptual Overview", in: Portes, Alejandro, ed., The Economic Sociology of Immigration. Essays on Networks, Ethnicity, and Entrepreneurship, New York, Russell Sage Foundation, pp. 1-41.

Rumbaut, Rubén G. (1999), “Assimilation and Its Discontents: Ironies and Paradoxes”, in: Hirschman, Charles - Kasinitz, Philip - DeWind, Josh, eds., The Handbook of International Migration: The American Experience, New York, Russell Sage Foundation, pp. 172-195.

Sárosi, Annamária (2011), “Az állampolgárságot kapott külföldiek jellemzése 
Magyarországon és az Európai Unióban” [Naturalized Migrants' Characterization In Hungary and the European Union], in: Kováts, András, ed., Magyarrá válni. Bevándorlók honositási és integrációs stratégiái [Becoming Hungarian. Migrants' Strategies for Naturalization and Integration], Budapest, Institute for Minority Studies, pp. 101-126.

Sassan, S. (1995) 'Immigration and Local Labor Markets'. in: Portes A. (ed.) The Economic Sociology of Immigration. Essays on Networks, Ethnicity, and Entrepreneurship, pp. 87-127. Russell Sage Foundation: New York.

Soysal, Yasemin Nuhu $\square$ lu (1994), Limits of Citizenship. Migrants and Postnational Membership in Europe, Chicago, London, The University of Chicago.

Süssmuth, Rita - Weidenfeld, Werner (2005), “The Integration Challenge: Living Together in a Europe of Diversity", in: Süssmuth, Rita - Weidenfeld, Werner, eds., Managing Integration. The European Union's Responsibility Towards Immigrants, Washington, Migration Policy Institute, pp. XI-XVIII.

Tóth, Judit (2011), “Az állampolgárság szerepe a migránsok beilleszkedésében” [Role of Citizenship in Migrants' Integration], in: Kováts, András, ed., Magyarrá válni. Bevándorlók honositási és integrációs stratégiái [Becoming Hungarian. Migrants' Strategies for Naturalization and Integration], Budapest, Institute for Minority Studies, pp. 13-64.

Zhou, Min (1999) 'Segmented Assimilation: Issues, Controversies, and Recent Research on the New Second Generation.' in: Hirschman, Charles - Kasinitz, Philip - DeWind, Josh, eds., The Handbook of International Migration: The American Experience, New York, Russell Sage Foundation, pp. 196-211. 